\title{
Where is our South? Locating new imaginative geographies in creative alliances between musicians from Portugal and the Arab world
}

\section{Leonor LOSA ${ }^{1}$}

Instituto de Etnomusicologia, Centro de estudos em Música e Dança (INET-Md).Faculdade de Ciências Sociais e Humanas.Universidade Nova de Lisboa

leonorlosa@gmail.com

Recibido 17/10/2016. Revisado y aprobado para publicación 12/12/2016.

Para citar este artículo: Leonor Losa (2016), "Where is our South? Locating new imaginative geographies in creative alliances between musicians from Portugal and the Arab world" en Revista de estudios internacionales mediterráneos, 21, 93-106.

Para acceder a este artículo: http://dx.doi.org/10.15366/reim2016.21.008

\begin{abstract}
Reflections on Portuguese orientalism have traditionally focused on the ways past historiographies of an academic penchant conveyed representations of "Arabs" and of their presence in explanatory theses about the Portuguese nation. This article focuses on how these kinds of statements form discursive archives which are handled within processes of subjective identification and acquire meaning in products and creative processes of expressive culture. Focusing on a musical collaboration between a Portuguese and a Lebanese musician, this seeks to understand how particular "imaginative geographies" emerging through sound, poetry and expressive practices dialogue with the current European economic and political context, in particular, the Portuguese.
\end{abstract}

Key Words: Ricardo Ribeiro; Rabih Abou-Khalil; cross-cultural empathy; vernacular orientalism; expressive culture

\section{Resumen}

La reflexión sobre un orientalismo portugués ha incidido especialmente sobre la forma en que la producción historiográfica de perfil académico vehiculó, en el pasado, representaciones de los "árabes" y de su presencia en las tesis explicativas de la nación. Este artículo plantea una reflexión

\footnotetext{
${ }^{1}$ This work was supported by the Fundação para a Ciência e Tecnologia (FCT) under grant SFRH/BD/76099/2011, by the POLIMUS Program, part of the Cluster of Excellence (Labex) "Pasts in the Present: history, heritage, memory" and by the Instituto de Etnomusicologia (INET). I am grateful to INET's President Salwa Castelo-Branco for her support.
} 
sobre el modo en que este tipo de enunciados constituyen aún hoy archivos discursivos que son manoseados en procesos de identificación subjetiva y que adquieren sentido en productos de la cultura expresiva. Colocando el foco de análisis en la colaboración entre un músico portugués y otro libanés, intento comprender cómo ciertas "geografías imaginativas" producidas a través del sonido, la poesía y las prácticas expresivas entran en diálogo con el actual contexto económico y político europeo y, en particular, con el portugués.

Palabras clave: Ricardo Ribeiro; Rabih Abou-Khalil; empatía cros-cultural, orientalismo popular; cultura expresiva.

Portugal's geographical position in the extreme west of Europe (bordered by Spain to the north and east, and the Atlantic Ocean to the south and west) along with geographic, cultural and historical characteristics led to a longstanding internal ambivalence concerning its cultural inscription in the Atlantic (meaning north) or the Mediterranean (meaning south) ${ }^{2}$. From a geopolitical point of view, Portugal's position in Europe has historically been peripheral. According to the Portuguese sociologist Boaventura de Sousa Santos (2002), despite the country's imperial history, its subaltern position points to a colonized condition vis-a-vis the rich European countries (particularly Great Britain).

The current European "crisis" leads to daily media coverage ${ }^{3}$ of those countries with economies that have lost or are at risk of losing the capacity to financially support themselves. Geographically, those nations are predominantly located in Southern Europe, along the cultural axis of the Mediterranean, which includes Greece, Italy, Spain, and Portugal. The current economic scenario has stimulated a political and media discursive inflection that has progressed from a conception of a unified Europe (especially after the adoption of the single currency in 2002) to a differentiated and regionalized Europe in which the south is conceived as underdeveloped, unregulated, and subject to paternalism, especially from the economically dominant countries and their banking institutions such as the German state and the European Central Bank. Both have been conditioning the internal policies of the Portuguese state- a gesture referred to, as in other countries, as "austerity politics" - therefore determining not only the course of life of the subjects of those countries but also the ways they imagine and position themselves within and on the margins of Europe.

This article departs from a paper presented at the conference "Peripheral Orientalisms in Lisbon" in 2014. At the time, the country was under an IMF financial rescue program and the corresponding "austerity policies" were undergoing their fullest implementation in a process incorporating aggressive, economically restrictive policies accompanied by discourses focused on ideas of patriotic resilience and overcoming. Political statements addressed whether the public or European institutions such as that issued by the deputy prime minister; "Rather Celitc than Greek but, in any case, always Portuguese" ${ }^{\prime 4}$ then strengthened the discursive disconnect of Portugal in

\footnotetext{
${ }^{2}$ A dichotomic reflection put forward by the leading Portuguese geographer Orlando Ribeiro, the anthropologist Jorge Dias (1952 and 1990) among other authors, which was critically reviewed and debated by the anthropologist João Leal (Leal 1999)

3 This article departs from a paper presented at the conference "Orientalismos Periféricos" (Peripheral Orientalisms; Lisbon, 2014).

${ }^{4}$ Jornal I 28/10/2013

94
} 
the south of Europe and the positions to the north. It is in this ideological backdrop that this reflection emerges ${ }^{5}$.

Based on a musical collaboration between the Lebanese oud player and composer Rabih AbouKhalil and the Portuguese fadista (fado singer) Ricardo Ribeiro, in this article I seek to understand how the "imaginative geographies" emerging through sound, poetic and expressive practices engage in dialogue with the current economic and political context affecting Europe and particularly Portugal. I apply Edward Said's term "imaginative geographies" to account for representations of "south" and "Middle East" that we might consider as a "new orientalism". These imaginative geographies seem grounded upon classical narratives about the origins and formation of the Portuguese nation and its identity that do not apparently present any conceptual novelty. However, I aim to focus on the subject, reflecting on the ways subjectivities undergo discussion within a context of instability and discursive change in the structures of power, and responded to in agentive modes, proposing new ways of conceptualizing their worlds. By taking into account a musical collaboration within the world music market, I aim to grasp how the intercultural and inter-subjective encounters underlying the creation of musical and expressive objects generate particular "structures of feeling" (Williams 1977) containing alternative statements and fostering new creative paths.

Portuguese orientalism has primarily been perceived from the axis of academic production to a greater or lesser extent in the fields of historiography, anthropology, archaeology and geography. Ana Rita Moreira (2013) and Maria Cardeira da Silva (2013), among others, have shown how production in these fields of knowledge within a context of national assertion and the construction of local identities has shifted between arabophilia and arabophobia. In turn, Raposo (2013) approaches the contemporary production of an orientalist imagination in the perspectives of performative representations of historical recreations of music and dance in Portugal, which target the internal and external tourism markets with the institutional support from cultural policy actors. This author reflects on the ways these representations of cultural proximity between Portugal and North Africa fuel creative projects and transits.

Nevertheless, it is also important to understand how the presence of "arabs" in the discourses of historical self-narration - a presence which Maria Cardeira da Silva identifies as constituting mere "movie extras" - configures discursive repertoires and resources handled by projects of individual identification. Departing from the current production of expressive culture, I aim to inquire about the ways orientalist representations produced in the context of official nationalist narratives acquire meaning in individual practices; and, furthermore, how these practices, in turn describe, change, question or accept the discursive worlds that they inhabit. I propose we complement the reading from Portuguese academic orientalism with an interpretation of an orientalism with a popular orientation, supported by expressive culture as a carrier of meaning and representation. The option to approach orientalist production articulated through expressive culture deemed "popular" stems from the fact of its trajectory arising "from below" and, as such, tendentiously more closely guided by the materiality of practices and in contrast with the discursive nature of

\footnotetext{
${ }^{5}$ I am grateful to Ricardo Ribeiro and Rabih Abou-Khalil for their generosity and for sharing their time, thoughts and music with me. I would also like to thank Maria Cardeira de Silva who first invited me to think on peripheral orientalism and challenged me to write this article; Rui Cidra, for his attentive reading and engaged debate; to Charles Hirschkind for his insightful and critical comments on the presentation of my first thoughts on this topic; and to the referees for their critical comments which contributed to strengthening this text.
}

REIM № 21 (Diciembre 2016) ISSN: $1887-4460$ 
academic production; and, on the other hand, due to the fact that this fits in with the field of material production and the symbolization of popular culture, conceived here as a marginal terrain of tension between hegemony and subordination (Hall 1981). Due to its nature, we may therefore refer to this as vernacular orientalism.

As a vernacular expression, the handling and production of orientalist representations should be understood as a part of larger processes of identification, processes wherein identities are constantly negotiated and emerge as "points of temporary attachments to the subject positions which discursive practices construct for us" (Hall 1996: 5-6). As I try here to show, academic orientalist production, despite fuelling an orientalism of popular bias, finds a field of political positioning in the latter that sometimes competes with official visions and institutional politics.

In this article, I address the reality of the creative intercultural encounter. To this end, I propose the operating concept of cross-cultural empathy. Empathy combines the emic meaning emerging from fieldwork of a sense of familiarity and intimacy with its classical definition - the ability to understand the feelings and emotions of the other without alienating the self. Thus, I refer here to cross-cultural empathy as the intercultural and inter-subjective process of creating emotional and creative alliances between different culturally, historically and politically localized selves.

This kind of musical collaboration circulates in the music industry under the label of world music. Ethnomusicological literature drew upon Said's work to debate world music as a transnational realm of western construction of difference and alterity (cf. Born and Hesmondhalgh 1997; Erlmann 1996; Stokes 2004). According to Veit Erlmann (1996), world music is a discursive and market category configured as "a new aesthetic form of the global imagination, an emergent way of capturing the present historical moment and the total reconfiguration of space and cultural identity characterizing societies around the globe" (Erlmann 1996: 468). This aesthetic of the global imagination rests on "an attempt by the West to remold its image by localizing and diversifying itself through an association with otherness" (ibid.: 469). Considering the phenomenon through the same analytical framework, Jocelyne Guilbault (1997) assumes, however, that scholarly reflection on local contexts promotes the understanding of different localized modes of creating "practices of meaning" around the attribution of global categories. For the author, world music stems from some commercial plot even while we still must also try to grasp just how this new label is located. I argue that Ricardo and Rabih's collaboration, while corresponding to Erlmann's aesthetic of the global imagination, allows for the creation of poetic and musical intertextuality between musicians from different geographical and political contexts that questions the classical construction of "imaginative geographies". This collaboration nurtures and motivates new practices of meaning in a critical moment of European and Portuguese political and economic change, which shapes and reflects local subjectivities as I explore below.

\section{Geographies of empathy: portraying a musical collaboration}

The collaboration between Rabih Abou-Khalil and Ricardo Ribeiro dates to 2005 when Rabih was invited by a Portuguese theater director to compose for poems by Portuguese poets. After hearing some Portuguese fadistas, Rabih invited the young fadista Ricardo Ribeiro to join the project as a singer. Since then, they have maintained a collaboration that extends far beyond the initial project and still remains productive in creative and professional terms.

Ricardo Ribeiro is a singer of fado, an expressive, social and urban popular music practice emblematic of Portugal, and particularly of Lisbon, that in 2012 was inscribed into the UNESCO list 
of Intangible Cultural Heritage of Humanity. Ricardo is now thirty-five years old and began singing in Casas de Fado (fado performance venues) at the age of twelve encouraged by an aunt. Henceforth, he has developed his style in contact with the celebrated fadista Fernando Maurício, among others, following a learning process that characterizes the musical and social practice of the fado milieu. Ricardo is referred to by both the media and his peers as an "heir to traditional fado", a statement that distinguishes him from the recently created category of "new fado" which incorporates most fado singers from his generation, some of whom perform on the world music circuit. Fado, a genre of urban popular music that first took shape in the second half of the nineteenth century and constitutes a strong emblem of expressive culture in Portugal, is currently undergoing a peculiar period. As a musical and social practice, it has experienced a history of marginalization characteristic of urban popular music style in many geographical contexts. In the last few years, especially after the disappearance of the main fado diva (Gray 2013) Amália Rodrigues, the genre has been popularly and- most importantly to shaping its historical trajectory - institutionally celebrated by the agents of local and global cultural politics. The apparent synchrony of popular and institutional forces led to the idea of drafting the fado application for UNESCO status as World Intangible Cultural Heritage. In 2011, UNESCO included fado on the world heritage list, placing it within a modern ordering of production, symbolization, and global celebration of the local.

Rabih Abou-Khalil, in turn, is a Lebanese musician whose professional career has developed in Germany, where he settled in the 1970s. After starting his music studies in Lebanon, where he attended the Beirut Conservatory for classical music in the Western tradition and Arab tradition (a common and institutionally promoted learning practice), he was encouraged by his father to leave Beirut during Civil war in 1975. At that moment, when he was seventeen years old, he went to Germany to complete his higher education. There, he attended Political Science, which he concluded simultaneously to higher studies in flute and musicology. After recording a first record with his own compositions to flute without any editorial support, he decided to devote himself to composing for the oud, an instrument that had been the main support in his learning of the Arab musical tradition. To his surprise, and contrary to what had happened with his compositions for flute, his work for the oud gained immediate commercial success, generating interest from major German record label publishers. He eventually signed for Enia Records (which had rejected publishing his works for the flute), the publisher with which he has henceforth worked.

Since then, collaborations with musicians from different cultural contexts have characterized Rabih's path as a musician and composer. The mixing of musicians coming from multiple musical traditions and with different professional and educational backgrounds represents an important part of his creative process, both stimulating him to compose and configuring his individual style and universe of imagination. Although he was a pioneer and preceded the emergence of the world music commercial label in the 1980s, over the years, his work was integrated into this broad category or in adjoining labels such as world jazz.

Rabih's work articulates modes of production characteristic both of popular music, particularly with its orientation towards record production and music dissemination, and Western art music with a demand on the technical skills and the music literacy of the musicians with whom he works. The son of a poet, he associates his family heritage with the particular way he addresses rhythm in his compositional style. While his rhythmic approach and tonal language move away from the Arabic musical tradition, one does not need musicologically trained hearing to recognize the 
affinities with what in the West gets roughly conceived as "oriental music". In a general manner, the predominance of the melodic (horizontal) thought over the harmonic (vertical); the homophonic texture between the different instruments (all instruments playing the same melodic phrase simultaneously); and a modal approach to tonality constitute the anchors of Rabih's musical approaches which incorporate generic characteristics of the Arabic musical tradition.

His work method and his constant collaboration with musicians from different traditions and musical cultures point to a cosmopolitan ethos which resonates with the cosmogony of his musical reflexivity. In a note in his biography and explaining how, in the Beirut of his youth, students were encouraged to pursue musical education both in the Arab and in the European musical traditions, Rabih mentioned that:

"I don't know how it is now, I think now it has changed, but I thought it was a very good idea, because it really opens your mind... I wouldn't have been able to do what I've been doing if I hadn't studied Western music, I wouldn't have even had the imagination to see from where to where expression can go (...) My father had this short wave radio (...) that was the radio I had as a child. And I was listening to music from all over the world, I was sitting there, you know, searching for things, because, you know, we are talking the 60s, early 70s. And so... I was just amazed... I remember, I still remember, actually thinking: how is it possible that a Chinese can be so happy listening to Chinese music like somebody from a completely different country is [listening to the music of their own culture] ... it is the same reaction, everybody is yeah! Clap, it's happy! If it's Indian, if it's Chinese, if it's... western, oriental, occidental... you know... it all seems to have the same effect. But [the music is] totally different, completely different! Nothing has do to with anything, you know (...) What always fascinated me was actually looking at it and thinking: wow, you know, imagine if I could feel what the Japanese guy feels, I could feel what the German guy feels, you know... how rich would you be emotionally if you could actually really listen to all of this and understand it, and feel as much as I would feel as listening to my own stuff, the stuff I like. I still like lot of rock music..."

At the annual "Dias da Música" festival, which takes place every spring in one of the main concert venues in the Portuguese capital (the Centro Cultural de Belém), I attended the concert of Rabih and Ricardo almost by accident. The festival Dias da Música presents an intense three day program of music concerts and stands out in the Portuguese context for being focused on Western Art music and for encompassing other styles and musical traditions, normally under a specific theme. In 2012, the "human voice" was the underlying theme of the festival which highlighted the sung repertoires of different historical periods and cultures.

I had seen an interview with Ricardo on a public television channel and although I did not have any affinity with fado, his reflexivity and musical and expressive approach aroused my curiosity. My trip to the festival therefore had the purpose of listening to Ricardo. As my musical training for many years had focused on becoming a musician, such events always come packed with meetings with former colleagues who work every year as musicians at the festival and with whom I would sometimes meet during concert breaks. While waiting for the doors of the Small Auditorium to open (the concert venue), I bumped into a friend who was playing in an orchestral concert taking place simultaneously in the Great Hall, the main concert venue, separated by a large outdoor hall. In the few quick words we exchanged, I told him I was attending Ricardo Ribeiro's concert. He told me he didn't know Ricardo and proceeded to express regret over having to play music that evening since Rabih Abou-Khalil was also playing and he would like very much to have attended the concert. I told him that we were talking about the same concert, Ricardo Ribeiro was about to 
sing with Rabih Abou-Khalil. He told me how he envied my luck because Rabih was an outstanding musician and he really wanted to see him performing.

As this short episode shows, to an ethnomusicologist, the different cultural backgrounds and the musical traditions at stake in this collaboration prove the most peaceful of the fields of questioning and conceptualization. As from 2013, I began closely accompanying the ongoing collaborative work between Ricardo and Rabih, above all following some of the concerts that they performed, holding interviews with both musicians, analysing the scores and the new repertoire that Rabih was composing based upon the Portuguese poetry chosen by Ricardo Ribeiro. In parallel, I advanced with fieldwork with Ricardo Ribeiro inquiring into his universe of relations, which comprised following his daily professional life as a fado singer on a daily basis as a resident singer in a fado house, his performances in concerts and in recording new individual works, and the collaborative projects that he continued with other Portuguese musicians. The musical profiles of these musicians are very distinctive attending to the fact that they belong to different generations and they face the different challenges and demands of the music industry that this lag encompasses. Rabih Abou-Khalil is a musician with a long and successful career, especially directed towards a broad Western audience. His extensive discography and the wide recognition of his work as a composer in a field of music production spanning from the market category of world music to jazz, position his career and his public image in the star system promoted and fuelled by the recording industry.

In turn, Ricardo Ribeiro is a young fadista. Although in recent years he has had great national projection and has managed to reach an international market sector that guarantees him recognition among fado and world music connoisseurs, his profile remains primarily associated with and directed towards the Portuguese public knowledgeable about and consumers of fado. Furthermore, despite being very active in terms of live performances and recordings within the Portuguese music industry, Ricardo maintains a daily occupation as the resident singer in the restaurant Faia, a fado venue ("casa de fados") in Lisbon's bohemian neighborhood of Bairro Alto where he sings every night. This type of activity is one of the more traditional practices of the fado urban economy, having historically provided the main professional activity of fado singers of older generations. In the last few years, the younger singers with residences in these fado venues usually have little or no expression in terms of the globalized economies of the music industry (record publishing and concerts). Although Ricardo states he continues to work in Faia due to failing to become financially autonomous from his other activities, remaining part of the casa de fados cast of singers, alongside recognized singers from previous generations, distinguishes his practice and way of life from those of the other fado singers of his generation.

The collaboration between Rabih Abou-Khalil and Ricardo Ribeiro resulted in a to a greater or lesser extent fixed live performance program that has been presented at jazz and world music festivals in Europe and the Middle East since 2007. They also came out with an album entitled em português ("in Portuguese"). All the songs were composed by Rabih Abou-Khalil in a style that mixes Arabic rhythms, instrumentation and melodic lines with rock and jazz instrumental techniques and styles and to which the fado vocal style is sometimes added. While the transnational nature of this record is not new, it is, however, an innovative project based on a creative dialogue between a Middle Eastern and a Portuguese musician. 
From the perspective of Ricardo Ribeiro, to become acquainted of Rabih Abou-Khalil was a crucial moment in his life. Having established a solid professional relationship, they simultaneously maintain a relation of friendship, affection and mutual admiration. Both musicians reflect on their musical encounter as something carrying strong meaning and describe their relationship in terms of empathy, musical and human understanding, a deep musical alliance and close intuition. For the first time in his career, Rabih Abou-Khalil developed compositions for voice. He had never before been comfortable doing this but, in his view, the success of the compositions rests on the fact that the metric of the Portuguese language (a language that he knows enough of to maintain an informal conversation) fits his particular rhythmic style. According to Ricardo, his success in interpreting Rabih's highly complex repertoire rests mainly on his intuition and on their sharing a close expressive idiom. The encounter between these musicians has been articulated by Ricardo through discourses on a cultural affinity anchored in a history of cultural contact within the Mediterranean. The historical permanence of the peoples of North Africa in Portugal between the 8th and the 13th centuries, alongside the permanent exchange between Portugal and Islamic regions in the past, constitute the objective facts justifying the cultural, subjective, emotional and musical proximity.

As Maria Cardeira da Silva argues, Portuguese academic orientalism has been characterized by its practical nature due to the fact that orientalist representations have mostly been produced in service of the explanatory thesis of the Portuguese nation, identity and the inscription of the country in Europe, either welcoming or repudiating cultural components, historical legacies and contacts between people. In both approaches, the "Arabs", according to this author, served as mere movie extras, participating in ethno-genealogical readings of the country's formation. This presence (sometimes felt even more as a result of its absence) in the self-explanatory narratives of the nation and its contours of identity, however, nourishes the archives of personal identity. As such, it also assumes a practical character whenever handled as a repertoire of subjective imagination. Furthermore, this conceals a rich analysis as the entailing political agenda sometimes competes with the one that produced and continues to institutionally produce Portuguese orientalism and in which these modes of imagining inscribe themselves. Calling upon the resources of history, language and culture and clamouring for a relation with a historical past, (those) personal identities are thus constituted "within, not outside representation" (Hall 1996: 4)

\section{Which South?/ Which sea?}

The latent debate of historiographic thought on fado, positioning the genre either on the Mediterranean axis or on the Atlantic, generically assumes the affinities of its producers and their personal interpretation of the discourses about the nation. In either case, they incorporate the multiculturalist discourse which precedes the official debates on national identity. Moving away from a narrative which brings the genre closer to the Atlantic, Ricardo Ribeiro- both in his discourse and in his musical approach - presents a form of "counter-memory", in the sense that he elects a historical narrative that currently stands on the margins. These positionings in relation to history are however inscribed in the present they inhabit in a localized way. Thus, by handling the official narratives of identity, they assume a political and agentive character. This proves even more so the case when, musicians handle this memory repertoire for practical purposes in the production of expressive culture as a material statement that eventually transcends personal identities in order to integrate broader archives of identity. Nevertheless, these discourses are supported by imaginary affiliations between distinct cultural and historical experiences. They account for the emergence of an imaginative geography of sharing and not excluding and in which difference is managed and framed emotionally. 
Musically, the voice and its expressive techniques as means of "emotional transformation" (Racy 2003:4) are seen as the unifying features of such practices as fado, flamenco and tarab. Ricardo Ribeiro referenced the affinities between fado and tarab in the Middle East in terms of an involving and expressive pathos, which establishes the main criteria for assessing the quality of the performer: the singer is only as successful as he or she is able to move the audience.

Besides this similarity between the concept of tarab and the affective dimensions of fado performances, Ricardo points to a musicological argument to support the closeness between musical traditions:

"... And also the style of singing [he sung an excerpt from Oum Kalthum] ... is very fadista, the way they sing, the way... even the form of the compositions... And then [also] it is very melodic, very rhythmic (...) there is virtually no harmony. I mean, there is harmony but it isn't either obvious or evident. Therefore, there is much melody, much rhythm... that is: melody, rhythm and poetry. This is what fado is. It happens like this. If you notice, if you listen to the so called traditional fados, they don't exceed the three chords, the triad, the tonic, dominant and sub-dominant (...) basically what is important is the melody, the rhythm and the words. As in the Arab world! The answers ... if we listen to Oum Kalthoum singing (...) the answers of the orchestra with the violins closely resembles how the guitar answers [in fado]. It is the same concept. I don't like the word "concept"... it is the same idea; the basis. The goal to achieve is the same, the goal of emotion, the aim of the heat of the words, the aim of sentiments expressed through music (Interview with Ricardo Ribeiro, 15.05.2012, Lisbon).

Although this kind of statement may be understood as a discursive formation, from a musicological point of view, fado displays several common traits with some Middle Eastern expressive practices, such as musical concepts and values; ethical modes of reflexivity; the centrality of the voice as a means of eliciting emotion; and dialogic forms of experiencing emotions through music (Shannon 2003 on tarab, or aesthetical ecstasy; Frishkopf 2001 on wajd or spiritual ecstasy).

Between April and August 2013, Ricardo Ribeiro recorded his third solo record, released in October of that year. The title of the record is Largo da Memória ("Memory Square"). Ricardo himself produced the album with a few interventions from the record publisher, Parlophone. Designed around the idea of "memory", it proposes, according to Ricardo, an innovative "looking back" at the history of Portuguese culture and the fado tradition. Both the choice of repertoire and his interpretive style are directed by an assumption of significant audible alliances with the south, which is a reflexive statement of the existence of a shared (cultural and emotional) geography.

In the current context, economic and cultural Portuguese policies have stimulated a dialogue with Portuguese-speaking countries (the former colonies of Portugal), materialized in the political category of Lusofonia ("Lusophony"): a constructed cultural space applying the Portuguese language as a core unifying element. Should the notion of Lusophony endow a primordial accent to the cultural and linguistic shared experiences, the market economy has certainly played a key role in strengthening ties between Brazil and Portugal. The Brazilian Lusophone context is twenty times bigger than the Portuguese reality and musicians from different fields of popular music production in Portugal aspire to commercially engage with it. 
The emergence of a new generation of fado singers, which we would describe as an "outbreak of fado" at the time of the application to UNESCO's Representative List of Intangible Cultural Heritage, stimulated a dialogue with musicians and modern music genres from Brazil. Commercially successful young fadistas like Carminho, António Zambujo or Raquel Tavares, among others, have recently engaged in record collaborations with established Brazilian musicians such as Chico Buarque, Ivan Lins, Caetano Veloso, among others. Likewise, the current academic production is tracing a genealogy of fado as an Atlantic genre with its origins in African-Brazilian practices (Nery 2004). Influenced by post-"Black Atlantic" (Gilroy 1993) trends, this new historiography of the genre competes with readings of fado as a genre that developed in a close relationship with cultural flows within the axis of the Mediterranean that framed most of literature on the genre during the second half of the twentieth century and still continues to be claimed by Ricardo and his collaborators.

In a conversation about the new conceptions of fado in the present, Ricardo stated: "Fado is a language. It goes from here to here. Inside this, you can do whatever you want. But if you go beyond it, then that is not fado. Within this, you can embellish (alindar), you can have your style". Then, in a critique of new fado's approaches to Brazil and its distancing from the fado tradition, he grabbed the guitar, played a harmonic progression in the style of Brazilian Bossa Nova and sang a melody without any words: "This is not fado. It can be beautiful and it is legitimate, but it is not fado, it's outside of the fado language" (Field notes, May 15, 2013).

According to Ricardo Ribeiro, fado is closer to the practices of the Mediterranean and the Middle East than to their cross-Atlantic counterparts. His conception of fado presents a clear opposition to that of the singers of his generation, especially by reinforcing an idea of a "tradition" that cannot be distorted. Ricardo frames this "tradition" according to historical projections of Portugal as an ancestral communal space of different cultures, and a sort of "foundational Arabness".

The historical ambivalence between an (official) Atlantic south, and a (historically implicit) Mediterranean south, gets framed by modes of interpreting the past in present practices. This is a practice-grounded process, founded on a particular way of understanding "tradition" that is based on discursive formations establishing, according to Saba Mahmood's terms, a "form of relation between past and present predicated upon a system of rules that demarcate both the limits and the possibility of what is sayable, doable and recognizable as a comprehensive event in all its forms" (Mahmood 2005:115).

An example that illustrates this process is "Fado do Alentejo", a song composed, in the early 1990s by the Portuguese musician Rão Kyao inspired on a poem by Rosa Lobato Faria. Despite being referred to as a fado, and integrating the informal songbook of the genre, according to the orthodoxy of Ricardo Ribeiro, from a formal point of view, this song does not constitute fado as it fails to comply with the metric, melodic and harmonic rules of the genre. It was nevertheless included in his recent recorded work with an arrangement for string quartet and oud by Rabih Abou-Khalil, who also performs. The poem focuses on a description of the Alentejo region (characterized by geographers, anthropologists and ethnologists as a characteristically Mediterranean region of Portugal). The poem focuses precisely on the natural and cultural elements of the region. The homophonic texture of Rabih's arrangement, the use of dynamic expressive voice, large melodic intervals, and octave changes, however, distances the song from the traditional universe of fado. 
Despite maintaining their autonomous, individual artistic careers and taking part in other and distinctive collaborative projects, ever since the beginning of their artistic relationship, Rabih and Ricardo have structured a part of their creative processes around continuing this artistic relationship. In addition to an active concert agenda mainly in Europe (Germany, France, Portugal) and the Middle East (Algeria, Lebanon, Morocco), these musicians have continued with the production of a new repertoire based upon the poetic selections of Ricardo Ribeiro ${ }^{6}$. Simultaneously, Rabih has participated as arranger and instrumentalist on the recent recordings by Ricardo Ribeiro. More recently, the composer, following a proposal by Ricardo Ribeiro, composed a symphonic work for the poem "Toada de Portalegre"7 by José Régio, which the pair played in conjunction with the Metropolitan Orchestra of Lisbon (in November 2016).

Taking into account the differences in their professional profiles and their potential scope of action in the marketplace, it is problematic to attribute a single, unified agenda to the expectancies of Rabih and Ricardo. Similarly, and given the nature of creative work (which has its own respective discourse and dispensing with discursive reflectiveness), I do not attribute any explicit political or ideological assumptions to the results of this collaboration. However, the creative options of Ricardo Ribeiro do position themselves within a broader universe, specifically as regards the production of fado in Portugal and the ways in which this genre enters into circulation within the global industry. In this sense, the creative universe that he expounds contains artistic statement that enter into interaction with the historical moment that fado is currently experiencing, representing a competitive orientation towards that which is, at the present, dominant.

The option initially taken to frame this type of affectivity through music as cross-cultural empathy seeks to convey personal aspirations and affective, creative and political dimensions in the ways of relating to difference. This framework of relations has been analysed in the field of music as musical cosmopolitanism, and, in this sense, the "cross-cultural empathy" may appear to resemble that of cosmopolitanism.

Debated within the critical scope of globalisation, the concept of cosmopolitanism falls within the broader debate of music within the frameworks of building and maintaining national musical projects on the one hand and of the dialectics among the possibilities for musical agency within the context of the hegemonic actions of the record industry on the other hand. In an article reviewing this concept in music studies, Martin Stokes (2007) proposes the need for an approach that focuses on the perspectives, aspirations and creativeness of musicians within the objective of ascertaining their positionings in the dialogues that frame the practices, styles and fashions of globalised dissemination. Appealing to the "musical imagination" as the core idea for thinking musical cosmopolitanism, he furthermore considers that 'to evoke 'musical cosmopolitanism' is to evoke a capacity of the musical imagination, and with that word 'imagination', certain ideas about the power, agencies and creativities of human beings at this point in time" (2007: 10). More recently, Steven Feld (2012) has drawn upon this concept to describe the creative practices and predispositions of the musicians with whom he worked in Accra. His approximation to that he

\footnotetext{
${ }^{6}$ One of the songs added to the initially recorded repertoire is a composition by Rabih Abou-Khalil for the poem "Mar Português" by the poet Fernando Pessoa, a poem that constitutes a statement on the Portuguese maritime expansion and setting out the values of sacrifice, overcoming and of a global sea.

7 This poem takes as its central reference the city of Portalegre in the Alto Alentejo region, making recourse to a form of pictorial description in support of its emotional realism.
} 
termed 'jazz cosmopolitanism' led to his focusing on this term as a process, advocating how it 'is about histories of listening, echoing, and sounding, about acoustemology, the agency of knowing the world through sound. (...) is the imagination and enactment of musical intimacy' (my italics) (Feld 2012: 49).

The framework of production of 'new imaginative geographies' through the actions of a vernacular orientalism that I have described above encounter resonances in the idea of musical imagination. However, while this idea of an affective approximation to the other may appear as that prescribed by the concept of cosmopolitanism, there are components that lead me to believe that this overlapping proves merely tangential.

Primarily, cross-cultural empathy emerges not so much as a universal value towards difference based on the common denominator of humanity but rather as a means of selective affinity that affectively and closely encompasses the other. However, secondly, as the term empathy conveys, this does not prove some unilateral process or an imaginative predisposition of the self, but rather happens as an intersubjective gesture with practical, dialogic and, following Bahktin, intertextual results. Framed by an orientalism emerging 'from below', the encounter between Ricardo and Rabih turns out to be a means of 'knowledge through music' that also reveals intimacy, expresses and generates new (creative) worlds of possibilities. Hence, cross-cultural empathy may be succinctly summarised as the intersubjective process of establishing and nurturing affective and creative alliances between culturally, historically and politically located selves.

\section{Final remarks}

The creative ways that Ricardo has been developing - especially after contact with Rabih AbouKhalil- integrate technical and expressive elements that approximate the practices roughly described as Middle Eastern. The integration of "Orientalist" features into his practice as a singer is self-reflexive but, nevertheless still supported firstly, by his belief in a shared expressive universe, and secondly, by the need not to exceed the limits of fado- its authenticity. The inflection is based on a search for authenticity in the past. This is simultaneously seen as a way of approaching tradition and a modern turn. For this reason, Ricardo entitled his latest recorded work "Memory Square", stating that "sometimes we have to take two steps back in order to move forward" (that is, we have to delve into the historical legacy in order to innovate).

Disrupting the official discourse, the strengthening of cultural ties within the Mediterranean world is based on a sentiment of cross-cultural empathy audible in the musicians' creative works. The construction of a shared emotional and geographical space based on Arab and Portuguese affinities through music promotes creativities, configuring marginal structures of meaning and conceptions of the world.

Should we understand agency not only as a form of resistance to relations of subordination but, as proposed by Saba Mahmood (2006: 133), as a way of action that can be inside of and motivated by those subordinate positions, the claims of cultural proximity between Portugal, the Mediterranean and Arab worlds that are creatively articulated by Ricardo represent an agentive mode of materializing the marginal condition that the "south" has assumed in Europe.

Simultaneously, the approach to the Orient configures itself as a counter-discourse vis-a-vis a cultural and market politics strongly oriented to the Atlantic and to the Brazilian market very much based on fado as a mediator. In this process, representations of the orient pursue a trajectory that range from an authoritative discourse to an identification mark and a creative background for the 
production of expressive culture. In this sense, this may indeed be understood as a vernacular orientalism, that is, one produced within broader discursive practices (Hall 1996: 4), as a way to frame and to endow meaning on the official narratives, and as a means of producing subjectivity. I argue, therefore, for the existence of a "new imaginative geography", which is not supported by discursive representations but by the materiality of practices. Although it perpetuates orientalist forms of representation, this geography, I believe, contains an emotional and poetic character based on intimacy and empathy, which does not seek to address the orient as some "foreign other" but rather strives to search for a foundational self there.

\section{Bibliography}

BORN, Georgina \& HESMONDHALGH, David (2000): "Introduction", en Born, Georgina e Hesmondhalgh, David (dir.) Western Music and Its Others- Difference, Representation and Appropriation in Music, Berkeley, Los Angeles and London, University of California Press.

CARDEIRA DA SILVA, Maria (cord.) (2013): Castelos a bombordo: etnografia de patrimónios africanos e memórias portuguesas, Lisboa, CRIA.

CARDEIRA DA SILVA, Maria $(2005,2013)$ : “O sentido dos Árabes no nosso sentido" en Silva, Maria Cardeira da (dir.) Castelos a Bombordo. Etnografias de Patrimónios Africanos e memórias Portuguesas, pp. 19-42, Lisboa, CRIA.

DIAS, Jorge (1952): "Bosquejo Histórico da Etnografia Portuguesa" en Revista Portuguesa de Filologia II, pp. 1 -64.

DIAS, Jorge (1953/1990): “Os Elementos Fundamentais da Cultura Portuguesa”, en

Estudos de Antropologia, Vol. I, Lisboa, Imprensa Nacional Casa da Moeda, pp. 135 -157.

ERLMANN, Veit (1996): "The Aesthetics of the Global Imagination: Reflections on World Music in the 1990's", Public Culture 8, pp. 467-487. https://doi.org/10.1215/08992363-8-3-467

FELD, Steven (2012): Jazz Cosmopolitanism in Accra, Durham and London, Duke University Press.

Frishkopf, Michael (2001): "Islamic Hymnody in Egypt: Al-Inshad al-Dini" en Danielson, Virginia (dir.) Garland Encyclopedia of World Music - The Middle East. Routledge.

GILROY, Paul (1993): The Black Atlantic: Modernity and Double Consciousness, New York, Verso. GRAY, Lila Ellen (2013): Fado Resounding: Affective politics and urban life. Durham, NC: Duke University Press.

GUILBAULT, Jocelyne (1997): "Interpreting World Music: A Challenge in Theory and Practice", Popular Music, vol. 16, pp. 31-44. https://doi.org/10.1017/S0261143000000684

HALL, Stuart (1981): "Notes on deconstructing 'the popular'" en Samuel, Raphael (dir.) People's history and Socialist Theory, London, Routledge, pp. 227-240.

HALL, Stuart (1996): "Who needs identity?" en Hall, Stuart and Du Gay, Paul (dir.), Questions of Cultural Identity, London, Sage.

LEAL, João (1999) "Mapping Mediterranean Portugal: Pastoral and Counter-Pastoral”. Nar.umjet, 36/1, pp. $9-31$.

MAHMOOD, Saba (2005/2012): Politics of Piety: The Islamic Revival and the Feminist Subject, Princeton and Oxford, Princeton University Press.

MAHMOOD, Saba (2006): "Teoria Feminista, Agência e Sujeito Liberatório: Algumas Reflexões Sobre o Revivalismo Islâmico no Egipto", Etnográfica, vol. X (1), pp. 121-158.

MOREIRA, Ana Rita (2013): “'Desorientalização', mestiçagem e autoctonia: o discurso historiográfico moderno sobre a nação" en Silva, Maria Cardeira da (dir.) Castelos a bombordo: etnografia de patrimónios africanos e memórias portuguesas, Lisbon, CRIA, pp. 43-63.

NERY, Rui Vieira (2004): Para uma história do fado, Lisbon, Público. 
RACY, Ali Jihad (2003): Making Music in the Arab World: The Culture and Artistry of Tarab, Cambridge, Cambridge University Press.

RAPOSO, Paulo (2013): “Mouros, Ventres e Encantadores de Serpentes. Representações do mundo árabe nas recriações históricas em Portugal e Espanha" en Silva, Maria Cardeira da (dir.) Castelos a bombordo: etnografia de patrimónios africanos e memórias portuguesas, Lisbon, CRIA, pp. 64-84.

RIBEIRO, Orlando (1945/2011): Portugal, o Mediterrâneo e o Atlântico, Lisbon, Letra Livre.

SANTOS, Boaventura de Sousa (2002): "Between Prospero and Caliban: Colonialism, Postcolonialism, and Inter-Identity", Luso-Brazilian Review, n.2, pp. 9-43. https://doi.org/10.3368/lbr.39.2.9

SHANNON, Jonathan (2003): "Emotion, Performance, and Temporality in Arab Music: Reflections on Tarab", Cultural Anthropology, vol. 18 n. 1, pp. 72.98.

STOKES, Martin. "Postcolonialism," en Shepherd, John, Horn, David, Laing, Dave, Oliver, Paul, Wicke, Peter (dir.) Continuum Encyclopedia of Popular Music of the World: Media, Industry and Society. A\&C Black

STOKES, Martin (2004): "Music and the Global Order", Annual Review of Anthropology, no 33, pp. 47-72.

STOKES, Martin (2007) "On Musical Cosmopolitanism". The Macalester International Roundtable 2007. Paper 3. http://digitalcommons.macalester.edu/int/rdtable/3

WILLIAMS, Raymond (1980/2005): Culture and Materialism, London, Verso Books. 